\title{
DINAMIKA KELOMPOK SENTRA PENYULUHAN KEHUTANAN DAN PEDESAAN MANGGA DELIMA TAMAN NASIONAL KARIMUN JAWA
}

\author{
Diarsi Eka Yani, Idha Farida \\ Staf akademik Program Studi Agribisnis Universitas Terbuka, Tangerang Selatan \\ Email: diarsi@ecampus.ut.ac.id
}

\begin{abstract}
Comprehensive development is a management process combined with the socio-economic aspects of the community, especially in the buffer zone of the National Park area. The community can play a role in extension activities through Forestry and Rural Extension Center (SPKP) in order to encourage productivity's enhancement and community's autonomy through various productive activities undertaken. The research objectives are (1) identify individual characteristics, and (2) analyze the dynamics of SPKP Mangga Delima Karimunjawa National Park group. The research used census method in SPKP Mangga Delima, Kemujan village, Karimunjawa distrcts. The research used census method in SPKP Mangga Delima, Kemujan village, Karimunjawa districts. There were 16 respondents that are members of the group. Data analysis used frequency distribution and description. The findings of individual characteristic are mostly (56,25\%) middle adult age (36-50 years old), formal education less than 9 years $(62,50 \%)$, less good cosmopolitan $(56,25 \%)$ participate in decision making $(87,50 \%)$, and join member less than 5 years $(62,50 \%)$. The findings for the dynamics of the group are most respondents consider the group objectives are good enough (50\%) and good (50\%), the group structure is good enough (56.25\%), the group task function is good (81.25\%), the coaching and group development is good enough (81.25\%), the group cohesiveness is good (62.5\%), the group atmosphere is good (56.25\%), the group tension is good enough (50\%) and good (50\%), the group effectiveness is good enough (50\%).
\end{abstract}

Keywords: group dynamics, Forestry and Rural Extension Center

\section{PENDAHULUAN}

Salah satu bentuk pemberdayaan terhadap masyarakat sekitar hutan yang efektif adalah melalui bentuk pemberdayaan kelompok. Pendekatan kelompok mempunyai kelebihan karena lebih luas daya jangkaunya, dan sesuai dengan budaya masyarakat pedesaan yang lebih komunal. Kelompok juga memiliki fungsi diantaranya sebagai wadah proses pembelajaran dan wahana dalam bekerjasama antar masyarakat (Utama dkk, 2010).

Perlindungan kawasan merupakan salah satu pilar pengelolaan kawasan Taman Nasional Karimunjawa. Upaya perlindungan ini diwujudnyatakan melalui berbagai kegiatan pengamanan kawasan yang dilakukan secara pre-emtif, preventif, dan represif. Dalam UU No. 16 tahun 2006 tentang Sistem Penyuluhan Pertanian, Perikanan dan Kehutanan tercantum bahwa pelaku utama dalam kegiatan kehutanan yaitu masyarakat di dalam dan di sekitar kawasan hutan.

Program penyuluhan dan pendampingan masyarakat dalam pengelolaan kawasan konservasi, merupakan sebuah langkah strategis dalam membuka keterbelakangan pola pikir masyarakat dalam aspek konservasi. Oleh karenanya, terbentuknya Sentra Penyuluhan Kehutanan Pedesaan (SPKP), diharapkan dapat memberikan ruang pembelajaran bagi masyarakat, khususnya mengenai pola-pola pemanfaatan sumberdaya alam hayati dan ekosistemnya secara arif dan bijaksana. Dengan keberadaan SPKP, masyarakat juga diharapkan mampu meningkatkan peran aktifnya dalam mendukung upaya konservasi di Taman Nasional Karimunjawa.

Sejak dibentuk pada tahun 2006, SPKP "Mangga Delima" di Desa Kemujan awalnya memunculkan optimisme akan terbangunnya skema pemberdayaan masyarakat yang partisipatif dan mendapat dukungan luas dari para pihak. Namun harapan dan cita-cita mulia SPKP belum tercapai dikarenakan berbagai permasalahan internal dan eksternal, yang secara komulatif telah berujung pada pengkondisian SPKP yang 
pasif dan memiliki keterbatasan peran. Kehadiran SPKP adalah memberdayakan masyarakat dan lembaga di tingkat pedesaan untuk berpartisipasi aktif dalam penyelenggaraan pembangunan hutan dan kehutanan. Sasaran penyuluhan kehutanan pedesaan adalah masyarakat yang terkait dengan keberadaan hutan baik secara langsung maupun tidak langsung.

Dinamika kelompok adalah gerakan bersama yang dilakukan oleh anggota kelompok secara serentak dan bersama-sama dalam melaksanakan seluruh kegiatan kelompok dalam mencapai tujuannya yaitu peningkatan hasil produksi dan mutunya yang pada akhirnya akan meningkatkan pendapatan mereka (Suhardiyono, 1992). Selanjutnya dinamika kelompok ini akan memberikan peluang untuk setiap anggota kelompok agar bekerjasama dan berpartisipasi dalam kegiatan kelompok. Dengan adanya partisipasi anggota kelompok, maka pembangunan pertanian / kehutanan dapat berhasil dan berjalan dengan baik.

Kedinamisan suatu kelompok sangat ditentukan oleh kedinamisan anggota kelompok melakukan interaksi dalam mencapai tujuan. Oleh karena itu, untuk mengetahui dinamis tidaknya suatu kelompok dan untuk mengetahui apakah sistem sosial suatu kelompok tersebut dikatakan baik atau tidak dan bagaimana kepemimpinannya dapat dilakukan dengan menganalisis kelompok melalui perilaku para anggota dan pimpinannya. Seperti yang diungkapkan Utama dkk (2010) yang menyatakan bahwa salah satu faktor yang berpengaruh terhadap dinamika kelompok adalah keefektifan kepemimpinan kelompok tani hutan. Kurang efektifnya kepemimpinan kelompok tani hutan menyebabkan rendahnya dinamika kelompok tani hutan tersebut.

Tujuan penulisan artikel adalah: (1) Mengidentifikasi karakteristik individu SPKP Mangga Delima Taman Nasional Karimunjawa, dan (2) Menganalisis dinamika kelompok SPKP Mangga Delima Taman Nasional Karimunjawa.

\section{METODE PENELITIAN}

Rancangan penelitian ini berbentuk explanatory research. Metode yang digunakan dalam pengumpulan data adalah sensus. Populasi dalam penelitian ini adalah semua anggota kelompok SPKP Mangga Delima yang ada di BNKT. Sampel diperoleh dengan metode sensus, yakni seluruh anggota SPKP Mangga Deli- ma sebanyak 16 orang.

Data yang dikumpulkan pada penelitian adalah data kuantitatif dan kualitatif. Jenis data yang dikumpulkan dalam penelitian ini adalah data primer dan data sekunder. Data primer diperoleh dengan menggunakan seperangkat daftar pertanyaan (kuesioner) yang diajukan kepada responden sampel dan dilakukan wawancara dengan responden dan informan. Analisis data dilakukan dengan distribusi frekuensi dan deskripsi.

Variabel pertama yang disajikan adalah karakteristik individu anggota meliputi (1) umur, (2) pendidikan formal, (3) tingkat kekosmopolitan, (4) tingkat partisipasi, dan (5) lama menjadi anggota. Variabel kedua adalah dinamika kelompok yakni, (6) tujuan kelompok, (7) struktur kelompok, (8) fungsi tugas, (9) pembinaan dan pengembangan kelompok, (10) kekompakan kelompok, (11) suasana kelompok, (12) ketegangan kelompok, serta (13) efektifitas kelompok.

\section{HASIL DAN PEMBAHASAN \\ Profil Kawasan dan Pemberdayaan Ekonomi Masyarakat}

Secara administratif kawasan Taman Nasional Karimunjawa (TNKJ) berada dalam wilayah Kecamatan Karimunjawa Kabupaten Jepara, Propinsi Jawa Tengah. Saat ini terdapat 4 desa yang berada di sekitar kawasan yaitu Desa Karimunjawa, Desa Kemujan, Desa Parang dan Desa Nyamuk yang diresmikan pada bulan Agustus 2011. Peta kawasan Karimunjawa seperti yang tertera dalam gambar 1 berikut.

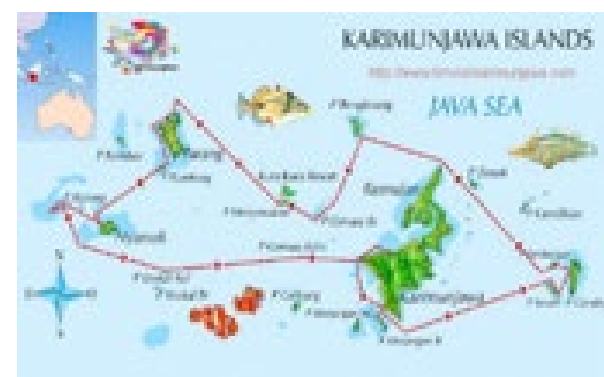

Gambar 1. Peta Kawasan Karimunjawa Sumber: http://www.timvisitkarimunjawa.com/2017/11/karimunjawa-islands-indonesia-paradise.html

Dalam upaya meningkatkan kesejahteraan masyarakat, para pemangku kepentingan telah memberikan berbagai bantuan untuk meningkatkan kapasitas masyarakat dalam pengembangan kehidupan ekonominya. Balai TNKJ selaku pengelola kawasan TNKJ berusaha manangkap 
aspirasi masyarakat yang hidup di sekitar kawasan dengan melakukan upaya pemberdayaan masyarakat dalam rangka mensejahterakan masyarakat melalui bantuan ekonomi masyarakat dan kegiatan pemberdayaan yang sinergis. Pada tahun 2016. Balai TNKJ melaksanakan kegiatan pemberdayaan masyarakat berupa pendampingan kelompok masyarakat dan Bantuan Pengembangan Usaha Ekonomi Desa Nyamuk dan Desa Parang. Namun berkenaan dengan penghematan anggaran hanya Kegiatan pendampingan Kelompok Masyarakat yang terealisasi. Kegiatan pemberdayaan masyarakat tersebut dikenal sebagai Kegiatan Pendampingan Kelompok Masyarakat Desa Penyangga.

Pemberdayaan masyarakat sesungguhnya telah dikejawantahkan dalam UU Nomor 41 Tahun 1999 tentang Kehutanan pasal 2 bahwa penyelengaraan kehutanan berazaskan manfaat yang lestari, kerakyatan, keadilan, kebersamaan, keterbukaan, dan keterpaduan. Lebih lanjut juga dijelaskan dalam UU Nomor 5 Tahun 1990 tentang konservasi sumberdaya alam dan hayati dan ekosistemnya, bahwa konservasi sumberdaya alam hayati dan ekosistemnya merupakan kewajiban dan tanggung jawab pemerintah beserta masyarakat.

Program pemberdayaan masyarakat TNKJ, diwujudkan melalui upaya pengembangan usaha ekonomi yang ditujukan untuk membuka peluang peningkatan kesejahteraan masyarakat. Kegiatan ini merupakan salah satu langkah yang perlu dijalankan untuk dapat menjamin keberlanjutan fungsi kawasan konservasi.

\section{Karakteristik Individu Responden}

Berdasarkan Siregar dan Pasaribu (2000), pendekatan sosiografis merupakan cara mengenali khalayak dengan mempertimbangkan latar belakang seseorang, seperti umur, jenis kelamin, pendidikan, dan posisi seseorang dalam kehidupan sosial.

Karakteristik individu adalah sifat-sifat yang ditampilkan seseorang yang berhubungan dengan semua aspek kehidupannya di dunia atau lingkungan sendiri (Reksowardoyo, 1983).

Pada penelitian ini, pendekatan sosiografis atau yang disebut sebagai karakteristik indivi$\mathrm{du}$ responden adalah umur, pendidikan formal, tingkat kekosmopolitan, tingkat partisipasi, lama menjadi anggota kelompok. Sebaran karakteristik individu responden dapat dilihat pada Tabel 1 .

\section{Umur}

Umur petani mempengaruhi kemampuan kerja fisik dan kematangan psikologisnya. Menurut Soekartawi (1988), petani yang berumur muda mempunyai daya kerja fisik yang kuat namun jika tidak dibarengi dengan kematangan psikologis sering membuat keputusan gegabah yang kadang merugikan dirinya sendiri. Seperti mudahnya terpancing untuk menerapkan input pertanian jenis baru yang belum teruji kualitasnya pada skala luas. Akan tetapi petani sudah tua juga cenderung kurang inovatif. Petani setengah baya cenderung yang paling tinggi adopsi inovasinya, karena kekuatan fisik dan kematangan psikologisnya saling mendukung. Pada Tabel 1 terlihat bahwa sebagian besar $(56,25 \%)$ responden termasuk ke dalam kategori dewasa tengah yakni usia 36 sampai dengan 50 tahun. Sejalan dengan pendapat Soekartawi (1988) tersebut, maka dapat dijelaskan bahwa anggota kelompok yang ada di SPKP Mangga Delima sudah siap menerima adopsi inovasi dari pihak luar. Hal tersebut juga dperkuat oleh pendapat Tambunan dkk (2005), yang mengatakan umur responden yang berada pada usia produktif memberikan peluang yang potensial bagi pengelolaan hutan mangrove yang partisipatif. Hal ini didasari atas kemampuan menyerap dan melakukan kegiatan partisipatif lebih besar kemungkinan berhasilnya pada usia produktif.

\section{Pendidikan Formal}

Tingkat pendidikan seseorang dapat mengubah pola pikir, daya penalaran yang lebih baik, sehingga makin lama seseorang mengenyam pendidikan akan semakin rasional. Secara umum petani yang berpendidikan tinggi akan lebih baik cara berfikirnya, sehingga memungkinkan mereka bertindak lebih rasional dalam mengelola usahataninya. Hal ini didukung oleh Soekartawi (1988), bahwa mereka yang berpendidikan tinggi adalah relatif lebih cepat dalam melaksanakan adopsi teknologi. Begitu pula sebaliknya, mereka yang berpendidikan rendah agak sulit untuk melaksanakan adopsi inovasi dengan cepat.

Temuan di lapangan tentang pendidikan formal responden yakni sebagian besar $(62,5 \%)$ termasuk kategori yang kurang baik, yakni menempuhpendidikan dibawah 9 tahun. Secara umum, temuan penelitian ini adalah para anggota berasal dari keluarga yang tidak sampai pada jenjang yang lebih tinggi dari SD. Alasan utama mereka 
Tabel 1. Sebaran Karakteristik Individu Responden

\begin{tabular}{|c|c|c|c|c|c|}
\hline \multirow{2}{*}{ No. } & \multirow{2}{*}{ Karakteristik Individu } & \multirow{2}{*}{ Kategori } & \multirow{2}{*}{ Rentang } & \multicolumn{2}{|c|}{ Jumlah } \\
\hline & & & & Jiwa & $(\%)$ \\
\hline \multirow[t]{4}{*}{1.} & \multirow[t]{4}{*}{ Umur } & Dewasa awal & $<36$ th & 4 & 25 \\
\hline & & Dewasa tengah & $36-50$ th & 9 & 56,25 \\
\hline & & Dewasa akhir & $>50$ th & 3 & 18,75 \\
\hline & & \multicolumn{2}{|c|}{ Total } & 16 & 100 \\
\hline \multirow[t]{4}{*}{2.} & \multirow[t]{4}{*}{ Pendidikan formal } & Kurang baik & $<9$ th & 10 & 62,5 \\
\hline & & Cukup baik & $9-12$ th & 5 & 31,25 \\
\hline & & Baik & $>12$ th & 1 & 6,25 \\
\hline & & \multicolumn{2}{|c|}{ Total } & 16 & 100 \\
\hline \multirow[t]{4}{*}{3.} & \multirow[t]{4}{*}{ Tingkat Kekosmopolitan } & Kurang baik & Tidak pernah & 9 & $\overline{56,25}$ \\
\hline & & Cukup baik & 1 kali & 6 & 37,5 \\
\hline & & Baik & $>2 \mathrm{kali}$ & 1 & 6,25 \\
\hline & & & & 16 & 100 \\
\hline \multirow[t]{17}{*}{4.} & \multicolumn{5}{|c|}{ Keterbukaan terhadap Inovasi } \\
\hline & \multirow[t]{4}{*}{ a. Teman } & Kurang baik & Tidak pernah & 6 & 37,50 \\
\hline & & Cukup baik & $1 \mathrm{kali}$ & 3 & 18,75 \\
\hline & & Baik & $>1$ kali & 7 & 43,75 \\
\hline & & \multicolumn{2}{|c|}{ Total } & 16 & 100 \\
\hline & \multirow[t]{4}{*}{ b. Kantor desa } & Kurang baik & Tidak pernah & 12 & 75,00 \\
\hline & & Cukup baik & 1 kali & 3 & 18,75 \\
\hline & & Baik & $>1$ kali & 1 & 6,25 \\
\hline & & \multicolumn{2}{|c|}{ Total } & 16 & 100 \\
\hline & \multirow[t]{4}{*}{ c. Penyuluh } & Kurang baik & Tidak pernah & 7 & 43,75 \\
\hline & & Cukup baik & 1 kali & 6 & 37,5 \\
\hline & & Baik & $>1$ kali & 3 & 18,75 \\
\hline & & \multicolumn{2}{|c|}{ Total } & 16 & 100 \\
\hline & \multirow[t]{4}{*}{ d. $\quad$ Media } & Kurang baik & Tidak pernah & 12 & 75,00 \\
\hline & & Cukup baik & 1 kali & 1 & 6,25 \\
\hline & & Baik & $>1$ kali & 3 & 18,75 \\
\hline & & \multicolumn{2}{|c|}{ Total } & 16 & 100 \\
\hline \multirow[t]{4}{*}{5.} & \multirow[t]{4}{*}{ Tingkat partisipasi } & Kurang baik & Tidak pernah & 1 & 6,25 \\
\hline & & Cukup baik & 1 kali & 1 & 6,25 \\
\hline & & Baik & $>2$ kali & 14 & 87,5 \\
\hline & & \multicolumn{2}{|c|}{ Total } & 16 & 100 \\
\hline \multirow[t]{4}{*}{6.} & Lama menjadi anggota & Kurang baik & $<5$ th & 10 & 62,5 \\
\hline & & Cukup baik & $5-10$ th & 5 & 31,25 \\
\hline & & Baik & $>10$ th & 1 & 6,25 \\
\hline & & & & 16 & 100 \\
\hline
\end{tabular}


tidak menempuh pendidikan adalah mayoritas karena faktor ekonomi, mereka menganggap sekolah membutuhkan biaya yang mahal dan tidak terjangkau oleh mereka. Temuan ini ternyata tidak sesuai dengan program pemerintah yakni Program Wajib Belajar Enam Tahun yang secara resmi dicanangkan pada tahun 1984 dan dilanjutkan dengan Program Wajib Belajar Pendidikan Dasar Sembilan Tahun yang dimulai pada tahun 1994. Program ini menargetkan pada tahun 2008, semua warga negara Indonesia memiliki pendidikan minimal setara Sekolah Menengah Pertama dengan mutu yang baik. Dengan bekal itu, diharapkan seluruh warga negara Indonesia dapat mengembangkan dirinya lebih lanjut sehingga mampu memilih dan mendapatkan pekerjaan yang sesuai dengan potensi yang dimiliki, sekaligus berperan serta dalam kehidupan bermasyarakat, berbangsa, dan bernegara. Sebagian besar responden di SPKP Mangga Delima di TNKJ menempuh pendidikan kurang dari 9 tahun ternyata juga terjadi di responden kelompok tani di kepulauan Untung Jawa, dimana anggota kelompok petani mangrove sebagian besar tamat SD (Yani, 2014). Namun demikian, latar belakang pendidikan tersebut tidak menjadikan anggota kelompok tidak menguasai teknik budidaya tanaman yang diusahakan, karena yang mempengaruhi perilaku seseorang, berupa pengetahuan, keterampilan, maupun sikapnya selain dipengaruhi oleh pendidikan formalnya juga dipengaruhi oleh pendidikan nonformalnya.

\section{Tingkat Kekosmopolitan}

Tingkat kekosmopolitan adalah keterbukaan petani terhadap informasi melalui hubungan mereka dengan berbagai sumber informasi yang dibutuhkan. Menurut Mosher (1978), keterbukaan seseorang berhubungan dengan penerimaan perubahan-perubahan seseorang untuk meningkatkan kualitas kegiatan usahatani mereka. Tingkat kekosmopolitan dicirikan diantaranya dengan aktivitasnya ke luar sistem sosial, misalnya pergi ke luar sistem sosial (ke luar desa), berinteraksi dengan pihak luar sistem sosial (tamu), atau kontak dengan lembaga penelitian, keterdedahan terhadap teknologi informasi dan komunikasi, baik dalam bentuk tercetak maupun elektronik.

Tingkat kosmopolitan petani dapat diketahui dengan mengetahui frekuensi petani keluar dari desanya ke desa lain atau ke kota dalam sebulan terakhir. Berdasarkan data Tabel 1, dapat diketahui bahwa tingkat kekosmopolitan responden kurang baik, yakni sebagian besar (56,25\%) tidak pernah ke luar pulau dalam 1 bulan terakhir. Alasan responden pergi ke desa lain atau ke kota, diantaranya adalah untuk bekerja, pelatihan, sekolah, mengantar anak sekolah, belanja barang, jual beli barang, menengok keluarga.

\section{Keterbukaan terhadap Inovasi}

Keterbukaan responden terhadap inovasi adalah sejauhmana responden mencari informasi yang terkait dengan kegiatan kelompok, baik melalui teman, kantor desa, penyuluh, ataupun media. Dalam pencarian informasi melalui teman, yakni sebagian besar (43,75\%) termasuk dalam kategori baik, yakni mencari lebih dari 1 kali perbulannya. Dalam perncarian informasi melalui kantor desa, ternyata sebesar $75 \%$ responden tidak pernah melakukannya dalam satu bulan terakhir. Sejalan dengan hal tersebut, ternyata pencarian informasi melalui penyuluh dan media juga kurang baik, yakni sebesar $43,75 \%$ responden tidak pernah bertanya ke penyuluh dan $75 \%$ responden tidak mendapat informasi dari media. Menurut pendapat Lionberger (1960), bahwa golongan masyarakat yang aktif mencari informasi dan ide-ide baru biasanya lebih inovatif dibandingkan dengan orang-orang yang pasif apalagi yang selalu tidak percaya terhadap sesuatu yang baru.

\section{Tingkat Partisipasi}

Tabel 1 menggambarkan bahwa sebagian besar tingkat partisipasi responden dalam kelompok termasuk baik, yakni sebesar 87,5\%. Pertemuan rutin di dalam kelompok dilaksanakan selama sebulan sekali. Indikator yang digunakan dalam partisipasi adalah sejauhmana keterlibatan para anggota dalam pengambilan keputusan, apakah mereka hanya menjadi anggota kelompok tetapi tidak aktif dalam pengambilan keputusan atau mereka aktif sebagai anggota kelompok sekaligus aktif dalam pengambilan keputusan di dalam kelompok. Disamping itu dilihat dari interaksi yang baik dari masing-masing suku yang ada di kepulauan Karimunjawa. Secara umum masyarakat kepulauan Karimunjawa tersusun dari beberapa suku yaitu Jawa, Bugis, Madura, dan Mandar. Keempat suku tersebut berbaur dalam SPKP Mangga Delima. Pola interaksi harmonis masyarakat Kepulauan Kari- 
munjawa tercermin juga dari semangat gotong royong yang masih melekat, kebersamaan dalam upacara adat dan lain-lain. Hal ini didukung oleh pendapat (Syahyuti, 2006) yang menyatakan partispasi dapat didefinisikan sebagai proses dimana seluruh pihak dapat membentuk dan terlibat dalam seluruh inisiatif pembangunan. Oleh karena itu pembangunan yang partisipatif adalah proses yang melibatkan masyarakat secara aktif dalam seluruh keputusan substansial yang berkenaan dengan kehidupan mereka

\section{Lama menjadi Anggota}

Lama menjadi anggota kelompok yang dimaksudkan adalah lamanya responden menjadi bagian dari SPKP dihitung sejak dia masuk/ terdaftar menjadi bagian dari kelompok, baik sebagai pengurus ataupun sebagai anggota, sampai saat penelitian ini dilaksanakan, ysng dinyatakan dalam tahun. Pada Tabel 1 dapat diketahui bahwa sebagian besar responden $(62,5 \%)$ menjadi anggota SPKP kurang dari 5 tahun.

\section{Dinamika Kelompok}

Menurut Yunasaf (1995), dinamika mengandung makna gerak, sedangkan kelompok diartikan sebagai suatu kesatuan sosial yang terdiri dari dua orang atau lebih yang dicirikan oleh adanya interaksi yang kontinyu dan relatif lama, kesadaran sebagai bagian dari anggota kelompok, kesepakatan bersama (norma yang berlaku, nilai-nilai yang dianut dan tujuan, atau kepentingan yang ingin dicapai) dan struktur hubungan (hubungan-hubungan antar peran, norma, tugas serta hak dan kewajiban). Sejalan dengan hal tersebut di atas menurut Jetkins (1961), dinamika kelompok diartikan sebagai gerak atau kekuatan yang terdapat di dalam kelompok, yang menentukan atau berpengaruh terhadap perilaku kelompok dan anggotanya dalam mencapai tujuan. Selanjutnya, Mardikanto (1993), menyatakan bahwa analisis dinamika kelompok dapat dilakukan dengan dua macam pendekatan, yaitu pendekatan psikososial dan sosiologis. Pendekatan psikososial adalah analisis dinamika kelompok yang dilakukan terhadap segala sesuatu yang akan berpengaruh terhadap perilaku anggota-anggota kelompok dalam melaksanakan kegiatan demi tercapainya tujuan kelompok, sedangkan pendekatan sosiologis adalah analisis terhadap proses sosial kelompok

Berdasarkan Slamet (2010), dinamika kelompok diamati melalui penilaian responden terhadap 8 dimensinya, yang diukur dengan cara mengetahui jumlah skor nilai dari komponen dimensinya. meliputi: (1) tujuan kelompok, (2) struktur kelompok, (3) fungsi tugas kelompok, (4) pembinaan dan pemeliharaan kelompok, (5) kekompakan kelompok, (6) suasana kelompok, (7) tekanan kelompok, dan (8) efektivitas kelompok.

Hasil penelitian Jafri, dkk (2015), faktor yang dapat memperkuat kapasitas kelompok tani adalah struktur kelompok, kekompakan/kebersamaan, efektivitas kelompok, dan karakteristik individu petani. Tabel 2 berikut ini adalah sebaran dinamika kelompok pada SPKP Mangga Delima.

\section{Tujuan Kelompok}

Berdasarkan Tabel 2, tujuan kelompok yang diketahui oleh anggota berada pada kategori cukup baik dan baik, yakni masing-masing sebesar 50\%. Tujuan kelompok perlu memberi arah pada kegiatan dan memberi kerangka bagi pengambilan keputusan yang rasional tentang jenis dan jumlah kegiatan yang harus dilakukan oleh kelompok yang menjadi kriteria pengukur kemajuan. Tujuan kelompok merupakan sesuatu yang harus dicapai bersama untuk keuntungan bersama (Slamet, 2010). Dengan demikian, sebagian besar anggota kelompok telah mengetahui arah tujuan kelompoknya. Terkait dengan tujuan, ada pendapat Ginting (2003) yang mengatakan tujuan organisasi merupakan unsur dinamika yang pernting karena berkaitan dengan motivasi anggota. Dengan keadaan pemahaman tujuan yang cukup baik (50\%) dan baik (50\%), mengindikasikan bahwa tujuan kelompok sudah dipahami dan dihayati oleh seluruh anggota, karena dengan pemahaman tujuan yang baik maka akan dapat menmberikan kerangka bagi pengambilan keputusan yang rasional tentang jenis dan jumlah kegiatan yang harus dilakukan oleh kelompok serta dapat dijadikan kriteria untuk mengukur kemajuan kelompok.

\section{Struktur Kelompok}

Struktur kelompok adalah bagaimana kelompok itu mengatur dirinya untuk mencapai tujuan (Slamet, 2010). Temuan pada Tabel 2 menggambarkan bahwa struktur kelompok SPKP Mangga Delima sudah cukup baik, yakni sebesar 56,25\%. Dalam kelompok ini sudah ada pembagian tugas dengan baik, dimana ketua kelompok membagi tugas 
Tabel 2. Sebaran Dinamika Kelompok

\begin{tabular}{|c|c|c|c|c|c|c|}
\hline \multirow{2}{*}{ No. } & \multirow{2}{*}{ Dinamika Kelompok } & \multirow{2}{*}{ Kategori } & & \multirow{2}{*}{ Rentang } & \multicolumn{2}{|c|}{ Jumlah } \\
\hline & & & & & Jiwa & $(\%)$ \\
\hline \multirow[t]{4}{*}{1.} & Tujuan kelompok & Kurang baik & & Skor 3-6 & 0 & 0 \\
\hline & & Cukup baik & & Skor 7-9 & 8 & 50 \\
\hline & & Baik & & Skor $10-12$ & 8 & 50 \\
\hline & & & Total & & 16 & 100 \\
\hline \multirow[t]{4}{*}{2.} & Struktur kelompok & Kurang baik & & Skor 3-6 & 0 & 0 \\
\hline & & Cukup baik & & Skor 7-9 & 9 & 56,25 \\
\hline & & Baik & & Skor $10-12$ & 7 & 43,75 \\
\hline & & & Total & & 16 & 100 \\
\hline \multirow[t]{4}{*}{3.} & Fungsi tugas & Kurang baik & & Skor 3-6 & 0 & 0 \\
\hline & & Cukup baik & & Skor 7-9 & 13 & 81,25 \\
\hline & & Baik & & Skor $10-12$ & 3 & 18,75 \\
\hline & & & Total & & 16 & 100 \\
\hline \multirow[t]{4}{*}{4.} & $\begin{array}{l}\text { Pembinaan dan pengemban- } \\
\text { gan kelompok }\end{array}$ & Kurang baik & & Skor 3-6 & 0 & 0 \\
\hline & & Cukup baik & & Skor 7-9 & 13 & 81,25 \\
\hline & & Baik & & Skor $10-12$ & 3 & 18,75 \\
\hline & & & Total & & 16 & 100 \\
\hline \multirow[t]{4}{*}{5.} & Kekompakan kelompok & Kurang baik & & Skor 3-6 & 0 & 0 \\
\hline & & Cukup baik & & Skor 7-9 & 10 & 62,5 \\
\hline & & Baik & & Skor $10-12$ & 6 & 37,5 \\
\hline & & & Total & & 16 & 100 \\
\hline \multirow[t]{4}{*}{6.} & Suasana kelompok & Kurang baik & & Skor 3-6 & 0 & 0 \\
\hline & & Cukup baik & & Skor 7-9 & 9 & 56,25 \\
\hline & & Baik & & Skor $10-12$ & 7 & 43,75 \\
\hline & & & Total & & 16 & 100 \\
\hline \multirow[t]{4}{*}{7.} & Ketegangan kelompok & Kurang baik & & Skor 3-6 & 0 & 0 \\
\hline & & Cukup baik & & Skor 7-9 & 8 & 50 \\
\hline & & Baik & & Skor $10-12$ & 8 & 50 \\
\hline & & & Total & & 16 & 100 \\
\hline \multirow[t]{4}{*}{8.} & Efektifitas kelompok & Kurang baik & & Skor 3-6 & 1 & 6,25 \\
\hline & & Cukup baik & & Skor 7-9 & 8 & 50 \\
\hline & & Baik & & Skor $10-12$ & 7 & 43,75 \\
\hline & & & Total & & 16 & 100 \\
\hline
\end{tabular}


kepada anggota kelompoknya, kemudian dikelompokkan dan dikoordinasikan secara formal. Hal ini diperkuat dengan adanya hierarkhi kepengurusan SPKP Mangga Delima. Selain itu dengan keberadaan kelompok diharapkan terjadi proses belajar dan mengajar antara petani dan penyuluh yang efektif dan efisien, yaitu terjadinya penyampaian informasi dari penyuluh dan pemecahan masalah petani. Pernyataan di atas didukung oleh pendapat Robbins (2007), bahwa struktur kelompok merupakan mekanisme pembagian tugas, mekanisme koordinasi serta pola interaksi yang diikuti.

\section{Fungsi Tugas Kelompok}

Menurut Slamet (2010) bahwa fungsi tugas adalah segala kegiatan yang perlu dilakukan di dalam kelompok dan diarahkan sehingga mampu melakukan kegiatan-kegiatan. Dalam hal fungsi tugas, sebagian responden $(81,25 \%)$ menilai bahwa fungsi tugas di dalam SPKP sudah cukup baik. Dalam Tabel 2, sebaran responden cukup baik $(81,25 \%)$ dalam melaksanakan fungsi tugas kelompok yaitu kepuasan anggota dalam mencapai tujuan, kelancaran arus informasi ke anggota, kesamaan pengertian tentang kegiatan yang dikerjakan.

\section{Pembinaan dan Pengembangan Kelompok}

Pembinaan dan pengembangan kelompok yaitu usaha-usaha yang berorientasi untuk memelihara kehidupan kelompok serta mengembangkannya (Slamet, 2010). Pembinaan dan pengembangan kelompok yang dirasakan oleh anggota sudah cukup baik (62,5\%). Hal ini tentu akan berdampak positif terhadap tercapainya tujuan kelompok

\section{Kekompakan Kelompok}

Menurut Slamet (2010), bahwa membina kekompakan kelompok adalah menumbuhkan keterkaitan yang kuat pada kelompok tani, yang menumbuhkan rasa kesatuan dan solidaritas. Sebagian besar responden (62,5\%) menyatakan bahwa kekompakan yang terjadi dalam kelompok cukup baik. Walau konflik kadang terjadi namun dapat diselesaikan secara kekeluargaan di dalam kelompok. Konflik dalam kelompok menurut March dan Simon (1985) mengandung beberapa hikmah antara lain : (1) pemecahan masalah lebih tajam, (2) saling menghargai perbedaan individu, (3) penawaran terhadap hal yang disetujui pun diterima, (4) kebijakan untuk mengambil koalisi pun bisa dimengerti.

\section{Suasana Kelompok}

Suasana kelompok adalah sikap mental dan perasaan-perasaan yang secara umum ada dalam kelompok (Slamet, 2010). Berdasarkan Tabel 2, suasana kelompok SPKP Mangga Delima berada dalam kategori cukup baik (56,25\%). Para anggota merasakan suasana keramahtamahan / kekeluargaan di dalam kelompok.. Antar anggota kelompok saling bekerja sama dalam memajukan kelompok. Contoh: kelompok bekerjasama dalam usaha persewaan ternak sapi yang terus berputar. Keuntungan dari usaha ini adalah untuk kepentingan kelompok. Hal tersebut sejalan dengan pendapat Ginting (2003), yang menyatakan bahwa nsuasana kelompok atau organisasin dipengaruhi oleh unsur-unsur tegangan, keramahtamahan, kelonggaran dan lingkungan fisik yang baik.

\section{Ketegangan kelompok}

Tekanan-tekanan pada kelompok dapat menumbuhkan atau memastika kedinamisan kelompok tani. Tekanan atau tegangan dapat bersifat internal, misalnya tuntutan-tuntutan dari para anggotanya sendiri untuk menghasilkan sesuatu bagi mereka. Sepanjang tuntutan tersebut masuk akal untuk dilakukan dan dipenuhi, maka hal itu dapat meningkatkan kedinamisan kelompok. Sedangkan tekanan/tegangan eksternal yakni tekanan yang datang dari pihak-pihak di luar kelompok yang sering pula dapat menumbuhkan dinamika baru, sepanjang masih dalam bats-batas kemampuan mereka (Slamet, 2010). Jika melihat temuan pada Tabel 2, maka dapat terlihat bahwa ketegangan yang terjadi di dalam kelompok dalam diselesaikan dengan baik. Separuh dari responden menyatakan cukup baik (50\%), dan separuhnya lagi menyatakan baik (50\%).

\section{Efektifitas Kelompok}

Keefektifan / keberhasilan kelompok akan cenderung meningkatkan dinamika kelompok (Slamet, 2010). Efektifitas kelompok adalah keberhasilan dalam melaksanakan tugas-tugas kelompok dalam mencapai tujuan. Semakin banyak tujuan yang dapat dicapai, semakin banyak keberhasilan, anggota kelompok akan semakin puas. Bila anggota kelompok merasa puas kekompakan dan kedinamisan kelompok akan semakin kuat. Hasil temuan penelitian ini menggambarkan bahwa efektifitas yang terjadi 
di dalam kelompok cukup baik (50\%). Artinya kelompok SPKP Mangga Delima cukup baik efektifitasnya. Terbukti adanya tujuan-tujuan kelompok dalam mencapai tujuan, sebagai contoh anggota kelompok mempunyai tujuan yang sama dalam menjaga kelestarian alam, melakukan kegiatan agrisilvikultur atau pertanian rakyat di areal kehutanan. Komoditas yang diusahakan adalah pohon jati dan sayur-sayuran. Hal tersebut sesuai dengan pendapat Gammahendra dkk (2014) yang menyatakan bahwa efektivitas organisasi merupakan ketepatan dalam pencapaian organisasi dalam meraih tujuan-tujuannya dengan memberdayakan sumber daya organisasi.

\section{KESIMPULAN}

Berdasarkan hasil analisis dan pembahasan, dapat disimpulkan beberapa hal sebagai berikut. Hasil penelitian mengenai karakteristik individu yakni, sebagian besar $(56,25 \%)$ umur responden berada pada kategori dewasa tengah (36-50 tahun), sebagian besar responden $(62,50 \%)$ mengikuti pendidikan formal kurang dari 9 tahun, sebagian besar responden $(56,25$ \%) memiliki tingkat kekosmopolitan kurang baik (tidak pernah keluar pulau), keterbukaan terhadap inovasi yakni sebagian besar responden mencari informasi yakni melalui teman 1 kali perbulan $(43,75 \%)$, tidak pernah mencari melalui kantor desa $(75 \%)$, melalui penyuluh lebih dari 1 kali perbulan $(43,75 \%)$, serta tidak pernah mencari melalui media $(75 \%)$, sebagian besar responden $(87,50 \%)$ turut berpartisipasi dalam pengambilan keputusan, serta sebagian besar responden $(62,50 \%)$ bergabung menjadi anggota kurang dari 5 tahun.

Hasil penelitian mengenai dinamika kelompok, yakni sebagian besar responden mengganggap tujuan kelompok cukup baik $(50 \%)$ dan baik $(50 \%)$, struktur kelompok cukup baik $(56,25 \%)$, fungsi tugas kelompok cukup baik $(81,25 \%)$, pembinaan dan pengembangan kelompok cukup baik $(81,25 \%)$, kekompakan kelompok cukup baik (62,5\%), suasana kelompok cukup baik (56,25\%), ketegangan kelompok cukup baik (50\%) dan baik (50\%), serta efektifitas kelompok cukup baik (50\%).

Berdasarkan temuan tersebut maka dapat diketahui bahwa fungsi penyuluh sebagai sumber informasi dapat dioptimalkan lebih baik lagi karena anggota kelompok belum banyak yang bertanya ke penyuluh dalam mencari informasi.

Dalam hal dinamika kelompok, struktur kelompok seperti pembagian tugas serta pembinaan dan pengembangan kelompok sangat penting untuk ditingkatkan mengingat SPKP Mangga Delima memiliki potensi yang cukup baik dalam mengembangkan para anggota kelompoknya.

\section{DAFTAR PUSTAKA}

Gammahendra, F dkk 2014. Pengaruh Struktur Organisasi terhadap Efektivitas Organisasi (Studi pada Persepsi Pegawai Tetap kantor Perwakilan Bank Indonesia Kediri). Jurnal Administrasi Bisnis (JAB). 2014. Vol 7. No. 2

Ginting M. 2003. Dinamika Organisasi dalam Mengukur Keberhasilan Koperasi. Di dalam: Yustina I dan Sudrajat A, editor. Dalam Membentuk Pola Perilaku Manusia Pembangunan. Bogor: IPB Press.

Hadipranata, A.F dan Sudardjo. Pengaruh Pembentukan Kelompok (Team Building) terhadap Etos Kerja dan Kontribusinya bagi Produktivitas Kerja Insani. Jurnal Psikologi. 1999. No. 1.18 - 28

Jafri, J., R. Febriamansyah, R. Syahni, dan Asmawi. 2015. Interaksi Partisipatif Antara Penyuluh Pertanian dan Kelompok Tani Menuju Kemandirian Petani. Jurnal Agro Ekonomi. 33 (2): 161-177.

Jetkins. 1961. What is Group Dinamic?. Edited by: Bradfors LP. Washington: National training Laboratories.

Lionberger, H.F. 1960. Adoption of New Ideas and Practise. USA: The Iowa State University Press

Mardikanto. 1993. Penyuluhan Pembangunan Pertanian. Surakarta: Sebelas Maret University Press.

Mosher, A.T. 1978. An Introduction to Agricultural Extension. New York: Agricultural Development Council.

Reksowardoyo. 1983. Hubungan beberapa karakteristik warga desa Sarampad kabupaten Cianjur dan persepsi mereka tentang ternak kelinci. [Karya Ilmiah]. Bogor: Fakultas Peternakan, Institut 
Pertanian Bogor.

Robbins S.P. 2007. Perilaku Organisasi. Jakarta: PT. Indeks.

Siregar, A., dan R. Pasaribu. 2000. Bagaimana Mengelola Media Korporasi Organisasi. Lembaga Penelitian, Pendidikan dan Penerbitan Yogyakarta (LP3Y). Yogyakarta: Kanisius.

Slamet, M. 2010. Materi Kuliah Manajemen Kelompok dan Organisasi. Bogor: Disampaikan pada Mahasiswa Program S2 Program Studi Ilmu Penyuluhan Pembangunan (PPN) Sekolah Pascasarjana IPB, Maret - April 2010.

Soekartawi. 1988. Prinsip Dasar Komunikasi Pertanian. Jakarta: Universitas Indonesia.

Statistik Balai TN Karimunjawa Tahun 2016. Kementerian Lingkungan Hidup dan Kehutanan.

Suhardiyono, L. 1992. Penyuluhan: Petunjuk bagi Penyuluh Pertanian. Erlangga. Jakarta.

Syahyuti. 2006. Konsep Penting dalam Pembangunan Pedesaan dan Pertanian. Jakarta: PT. Bina Rena Pariwara

Tambunan, R, R. Hamdani Harahap, Zulkifli Lubis. 2005. Pengelolaan Hutan Mangrove di Kabupaten Asahan. Jurnal Studi Pembangunan. 2005, Vol.1, No.1. Hal 64

Utama, S., Sumardjo, D. Susanto, D.S. Gani. 2010. Dinamika Kelompok Tani Hutan pada Pengelolaan Hutan Produksi Bersama Masyarakat di Perum Perhutani Unit I Provinsi Jawa Tengah. Jurnal Penyuluhan. 6 (1): 49-64.

Yani, D.E. 2014. Adopsi Inovasi Budidaya Mangrove di Pulau Untung Jawa Kepulauan Seribu. Jurnal Sosial Ekonomi Pertanian. Vol 7. No. 2. Hal $21-30$.

Yunasaf, U. 1995. Organisasi Sosial dan Kepemimpinan Laboratorium Sosiologi dan
Penyuluhan. Jurusan Sosial Ekonom Peternakan, Universitas Padjadjaran. Bandung. 